\title{
The Profession
}

\section{The Women's Caucus for Political Science: Five Views of Its Significance Today}

The founding of an organization, especially when it takes place at a time of turmoil in a nation and is itself symptomatic of that turmoil, creates a story best told by a single voice. When that voice belongs to someone who was there, who has kept the records as well as the faith, and who knows how to tell it like it was-in short, someone like Joyce Mitchell-the organization is fortunate indeed. (PS, June 1990).

In this second article, we keep the individuality of single voices while covering a many-faceted story. Barbara Nelson, past president of the Caucus, tells what the Caucus has tried to do about two key problems; sexual harassment and the access of women political scientists to the publication network. Pamela Conover, chair of the Committee on the Status of Women, covers its sometimes complex but always symbiotic relationship with the Caucus. Jewel Prestage considers what the Caucus might do to improve its recruitment of black women. Joan Tronto examines what the Caucus means to its new and younger members, as they take over and redefine its mission, a process both inevitable and desirable for the Caucus to grow and prosper. And, finally, Kay Lawson, president of the Caucus 1989-90, concludes by examining two ongoing Caucus projects: The American Government Textbook Award and The Women's Platform.

\section{Promoting the Careers of Women Political Scientists: Stopping Sexual Harassment, Opening the Journals}

\section{Barbara Nelson,} University of Minnesota

One of the important and enduring goals of the Caucus is to promote the careers of women political scientists, regardless of field of specializa- tion and location of employment. Beginning with the premise that women often experience the workplace and career opportunities differently from men, the Caucus seeks to promote awareness of the barriers women face, to design policies that remove those barriers, and to provide

One of the most persistent limitations in career development is inadequate access of women scholars

to the publication

network.

positive support for disciplinary and American Political Science Association policies and programs that enhance women's career opportunities.

Perhaps the most distinctive difference between the sexes is that women are more likely than men to be the targets of sexual harassment.

Adrienne Rich has said that it is difficult for a woman to be a scholar if she must fear walking home from the library at night. But it is also difficult for a woman to be a scholar if she must fear going to the office in the morning. The Caucus has played an important role in raising this once taboo subject, by offering workshops on law, policy and administrative responses at national meetings, and by working with the APSA to craft Association policy in this area. Regional caucuses have also held successful meetings on this topic for departmental chairs at their conventions.

The Association's policy recognizes sexual harassment as unethical, unprofessional, and illegal under Title VII of the 1964 Civil Rights Act and Title IX of the 1972 Educational Amendments. It defines sexual harassment as "unwelcome sexual advances, requests for sexual favors, and other verbal or physical conduct of a sexual nature when (1) submission to such conduct is made either explicitly or implicitly a term or condition of an individual's employment or academic achievement, or (2) submission to or rejection of such conduct by an individual is used as the basis for employment decisions or academic decisions affecting such individuals, or (3) such conduct has the purpose or effect of unreasonably interfering with an individual's work or academic performance or creating an intimidating, hostile, or offensive wórking or academic environment."

The implementation clauses of the APSA policy are the subject of continuing discussion. The current policy statement says that "when a political scientist is dismissed, not reappointed or suspended from employment"' on grounds of sexual harassment, the Association will, at the recommendation of the Ethics Committee, inform its members through $P S$." The statement also says that the Committee on Professional Ethics, Rights and Freedoms "stands ready to respond to complaints of sexual harassment." Concern has been voiced in the APSA Council that the Ethics Committee may not be equipped to undertake such an investigation, and that the committee might also be accountable for not acting even if it were not equipped to act. The Council will continue to discuss this concern. Meanwhile, its Committee on Sexual Harassment, under the leadership of Roberta Johnson, has prepared a brochure describing the Caucus' position on this serious matter in greater detail; it will be ready for distribution soon.

One of the most persistent limitations in career development is inade- 
quate access of women scholars to the publication network. These limitations affect every aspect of professional life, from the opportunity to raise research money to the timing and success of promotion decisions. The Caucus and the APSA Committee on the Status of Women have undertaken an analysis of the number of articles in any field published by women, the number of articles published in the field of women and politics, and the number of women on editorial boards.

In any journal, the number of articles published by women or in the field of women and politics depends on a great many factors, including the number of articles that are submitted by women. Thus the numerical findings about women's access to any particular journal can only be suggestive. Yet on a numerical basis the findings do give cause for concern. A look at the American Political Science Review from 1978 through 1988 is instructive in this regard. In that decade, $8.0 \%$ (69 of 862) of the authors of articles published in the Review were women, and less than $1 \%$ (5 of 552) articles were on the subject of women and politics.

Those studying women's access to journals believe the key issue is the intellectual climate of a journal, not a conscious attempt made to exclude a particular group of scholars or topics. To increase the representation of women scholars and studies of women and politics requires a serious effort to communicate that the journal welcomes articles by and about women. That message is communicated in a number of ways: by including women scholars from many fields on editorial boards; by making an effort to ensure that scholars who work on women and politics are represented on editorial boards; by recognizing the diversity of women political scientists and of women and politics scholarship; and by developing lists of women reviewers in all fields. The evidence suggests that waiting for more women to enter the discipline will not in itself make much difference. The percentage of women authors and of women and politics articles has not increased in the last decade despite the increase in the number of women scholars and their progress through the academic ranks. In fact, the percentage of women on the APSR editorial board was at a decade low in $1988(8.0 \%$, one out of twelve). Increased access to publication outlets for women requires the committed leadership of journal editors. The Caucus counts on them, and will continue to monitor developments in this important domain.

The percentage of women authors and of women and politics articles has not increased in the last decade despite the increase in the number of women scholars and their progress through the academic ranks.

\section{The Caucus and the Committee on the Status of Women}

Pamela Conover, University of North Carolina

In 1969, the same year the Caucus established itself, the American Political Science Association established a Committee on the Status of Women (CSW). Although members of the CSW are appointed by the APSA president with the approval of the Executive Council, the Caucus makes recommendations, and its recommendations are taken seriously. Typically, the CSW is composed of women and men who are sympathetic to the Caucus and who often are members of the Caucus as well.

Why have both CSW and the Caucus? In practice, the concerns of the CSW are distinct from those of the Caucus and the more recently formed Organized Section on Women and Politics. Although it is true that all three groups are concerned with the status of women in the profession, and often work together, there are important differences. The Caucus, affiliated with but not a constituent component of the Association, may take up politi- cal issues and engage in political activities. The Organized Section on Women and Politics gives its attention to substantive research, a matter of concern as well to the Caucus (most of the panels on this subject are routinely co-sponsored by the two groups). But neither a concern with political issues nor substantive political research is appropriate for the CSW. Instead, the CSW is best understood as the formal voice of APSA for addressing problems and issues having to do with the status of women within the Association and the broader discipline of political science. It can bring the often formidable resources of the Association to bear on such problems in ways that the Caucus cannot; on the other hand, it is constrained in its activities in ways that the Caucus is not.

An examination of CSW projects over the years makes this distinction more clear. The CSW has sponsored or co-sponsored such publications as the Roster of Women in Political Science, the Roster of Black Women in Political Science, and $A$ Guide to Publications in Political Science. It has consulted with the APSA Committee on Professional Ethics, Rights and Freedoms about grievance procedures, particularly as they concern women political scientists. In the 1980s these efforts culminated in the Association's adoption of a policy statement on sexual harassment. More recently, the CSW cosponsored with the Committee on Education an important project whose central goal was to "mainstream" instructional materials on women and politics into the teaching of American politics. This project produced instructional materials that are now available to the discipline as a whole. ${ }^{1}$

Other CSW projects have more directly involved the Caucus. Every year the CSW joins with the Caucus in preparing recommendations for the APSA Committee on Nominations. Through the years the Caucus and the CSW have come to work closely with one another in coordinating convention activities. The CSW regularly co-sponsors with the Caucus convention receptions for women political scientists and their friends. The CSW often joins with the Caucus in co-sponsoring panels 
on topics of mutual interest. Both groups have made important contributions to the establishment and evolution of the convention's child care and roommate matching services.

Cooperation between the CSW and the Caucus continues to be good and is facilitated by the attendance of the Caucus' president at the annual meeting of the CSW. Currently the two groups are working together on a number of projects, including a CSW report on how to eliminate sex inequities in departments of political science across the nation.

\section{The Caucus and Black Women: An Agenda for Change}

Jewell Prestage,

Prairie View A\&M University

"Jewel Prestage, a woman and a Negro, endorsed by all three major groups plus the Black Caucus, was a sort of one man coalition of minority groups in this election. . ." (Mueller, Summer 1970, 313).

In 1970 the low level of participation by women and minorities in the American Political Science Association was a source of rising dissatisfaction; a "coalition of minority groups," as visualized in the above report on the Executive Council elections, was confidently expected by some to help resolve this problem. However, such a coalition did not materialize. Its absence is nowhere more apparent than in the role of black women in the Caucus.

Records indicate that few black women have held leadership positions in the Caucus and, in fact, the number holding Caucus membership has been extremely limited. This limited involvement has been attributed to: the preoccupation of black women with racial discrimination within the profession (a view supported by the highly visible and prominent role played by black women in the National Conference of Black Political Scientists since its founding in 1969); the small number of black women with Ph.D.'s in political science (estimated at five in 1969 and at less than 100 in 1989), and the feeling on the part of black women political scientists that their
Caucus colleagues are either unaware of or insensitive to the special concerns of black women political scientists. Now, 21 years after the founding of the first Committee on

\section{The literature on women}

in higher education

suggests that mentoring is

very important at every

stage in the career ladder

-from precollegiate

schooling to tenure,

promotion, and other

activities associated with

upward mobility.

the Status of Women, the first

Committee on the Status of Blacks, and the Caucus itself, an examination of the future of black women in political science and in the Caucus would seem to yield several specific concerns and possible directions for action.

1. There is a paucity of literature on black women in higher education and in political science. However, a recent survey of black women with political science Ph.D.'s reveals some information about their predoctoral career development. One dimension probed was the graduate study experience. Just over $74 \%$ of the women feel that "good" relations with fellow graduate students are important to success in graduate school, and $81 \%$ found such relations to have been at least "reasonably cordial and mutually respectful" in their own cases. On the question of relations with graduate faculty members, $21 \%$ described the situation as "mostly indifferent" $(14 \%)$ or "hostile, distant, negative" $(7 \%)$. Black women graduate students experience the normal stress associated with graduate study, the gender-related stress attendant to being female, and racially based stress as well.

2. The literature on women in higher education suggests that mentoring is very important at every stage in the career ladder-from precollegiate schooling to tenure, promotion, and other activities associated with upward mobility. Of the black women Ph.D. holders studied, $37.2 \%$ had no mentor in undergraduate study, $25.6 \%$ had none at the master's level, and $16.3 \%$ completed the Ph.D. without a mentor. Role models were absent for $46.5 \%$ at the undergraduate level, for $60.5 \%$ at the master's level, and for $48.8 \%$ at the Ph.D. level. Of particular interest is the fact that black women do not tend to list "teaching me well" or "providing me with appropriate research skills" as the major contributions mentors have made to them. Instead, human relations ranked higher: "he told other faculty members about me," "he really did nothing but I knew that he was there if I needed him," "he helped me through the politics of the department." Apparently a support system, beyond the teaching and research expertise provided, is a critical element in the lives of black female graduate students (Prestage, 1989).

3. Study of the political behavior of black women has received only scant attention in the literature of the discipline. While the APSA now offers awards for books in the subfield of "Minority Politics" and "Women in Politics," and several regional associations offer similar incentives, little of the literature considered for these awards has focused on black women in politics.

4. To date black women program participants are more a rarity than a common element at APSA and regional political science meetings.

5. Popular media, higher education publications, and numerous special reports document an increase in the number of racial incidents on predominantly white campuses in all regions of the country. In a related development, a recent survey of college and university professors found nearly half satisfied with the level of affirmative action achieved on faculties and another $21 \%$ not concerned (Houston Chronicle, November 6, 1989, 3A). Ernest Boyer has pointed out that not only is minority faculty recruitment not moving ahead, it is sliding backward. Faculty members either do not know, do not care, or approve (Houston Chronicle, November 6, 1989, 3A). 
What are the implications for the Caucus?

First, identifying black women professionals and preprofessionals and asking them what needs they have that the Caucus might be able to meet and what ways they feel they might become effective members of the organization could be an important first step to expanding black women's participation.

Second, as the number of white females on political science faculties increases, the possibility for female bonding across racial lines might be enhanced because white women faculty will have greater opportunity to relate to the racial stress, as well as to the other forms of stress faced by black female graduate students. Such an effort would contribute not only to the well-being of the students, but would also improve and broaden the understanding of the white female faculty, as they serve as role models and mentors.

Third, another possible area of increased interaction is in the area of research and writing, especially in studies of women in politics. The saliency of race in American politics indicates that co-investigations by political scientists with different life experiences and perspectives might yield positive results for the expanding literature of this subfield. Yet racially diverse research teams in this area have so far been extremely rare.

Fourth, amid the widespread publicity about the current wave of racially motivated incidents on American campuses any well-documented Caucus initiated/sponsored report would increase the information base on which policymakers concerned about these developments could rely.

Perhaps there is still a possibility that our profession could yet witness a meaningful "coalition of minority groups." At least the decision by the Caucus to devote part of this special section of PS to the question of the relationship between two easily identifiable minority groups is encouraging.

\section{Life After Twenty? What the Caucus Means to New Members}

\section{Joan Tronto, CUNY-Hunter College}

Since the Caucus is now 20 years old, it may seem a relic of a bygone age when sexist dinosaurs roamed the earth. To an outsider it may seem that, in these more enlightened days, the need for such an organization has passed. I would like to address the question whether the Caucus continues to work well for its new members.

Let's face it: women academics still have a hard time being fully accepted

\section{Women are expected to fit their careers into lives with families and to bear primary responsibility for family.}

professionally. Despite the progress women have made in the profession, despite the decline in overt forms of sexism, despite the good will of many, a number of structural factors in the academy and in women's lives still conspire to make it more difficult for women to succeed. In their excellent book, Women of Academe: Outsider in the Sacred Grove, Nadya Ainsenberg and political scientist Mona Harrington identify a number of these factors. Women are expected to fit their careers into lives with families and to bear primary responsibility for family. Women are almost always numerical minorities in their departments and may be treated as tokens. Women conceive of their scholarly work in different terms: their subjects tend to be more integrative and thus somewhat more difficult to complete and to publish (Aisenberg and Havington, 1988).

While not all women have these problems, one of the most insidious and central problems of all is that women often perceive their burdens as uniquely theirs. They struggle valiantly, certain that only their own weaknesses cause them to struggle. The result is a sense of psychological isolation that exacerbates all the other problems. From a position of isolation, one assumes either the best or the worst. With little real information about whether one is acting correctly or not, the inevitable result is a high level of anxiety. This isolation can be devastating even if one manages to succeed by usual professional standards (Cross, 1986).

The Caucus helps to overcome isolation in several ways. First, arriving at a Caucus breakfast meeting to see scores of other women political scientists made it obvious to me that I was not alone! I listened to the discussions, attached names to people, and made some judgments about some of the issues under discussion. I found myself speaking to and eventually becoming friends with scholars whom, in our increasingly sub-disciplined profession, I might otherwise never have met. The Caucus cocktail party also proved delightful, unlike many others I have felt obliged to attend over the years. The Quarterly provides practical advice that we need but do not always receive. For example, I found especially useful an article on what makes a good letter of recommendation for promotion and tenure.

The Caucus supports ideas that make good professional sense in creative ways. The recent awards ceremony honoring those who had served as mentors was a good way to encourage mentoring, but it also made me think about the possibilities for more systematic approaches to mentoring. All in all, the Caucus provides camaraderie, advice, and above all, a sense of reassurance.

Carving out a niche for ourselves in political science is difficult; it is still more difficult to figure out how that professional niche fits with our personal and political commitments. Insofar as the Caucus has provided me with a supportive atmosphere in which to think about these questions, it has helped me tremendously.

While business meetings can have their tedious moments, on balance I have gained more than I have given up. Even if you think a breakfast meeting is too early, even if you do not normally go to the annual meetings, and especially if you think that you do not need the support of 
others, you may be surprised, like me, to find how helpful the Caucus can be.

\section{Work in Progress: The American Government Textbook Award and the Women's Platform}

Kay Lawson, San Francisco State University

The Caucus is now a complex and hard-working organization. Its 14 committees are at work on everything from investigating opportunities for nonacademic and administrative careers, to finding new ways to combat sexual harassment, to assessing the progress women are making in the discipline, to improving recruitment of women of color, and of women political scientists in general. In this final section I want to tell you about the work of two of the newer committees: the American Government Textbook Award Committee and the Women's Platform Committee.

The American Government Textbook Award is given by the Caucus every three years to the best introductory text in the area of American government. To qualify, a textbook must be of generally high quality across all the usual criteria and, in addition, offer full and substantial coverage of women's issues and women's participation in politics. The prize was first awarded in 1988, when the winners were Susan Welch, John Gruhl, Michael Steinman, and John Colmer, for the second edition of their text, American Government, published by West Publishing Company in 1986.

The purpose of the committee is not merely to find a prize winner but also to do some consciousness raising. Publishers of more than 100 texts were asked to send copies of their books for review, a task shared by 80 members of the Caucus, and reviewers were asked to send copies of their reviews to the publishers. Sixty-six books were reviewed, some by two different reviewers (although the committee's goal of having two reviews for every book proved impossible to meet). Each review consisted of a completed 34-item questionnaire, covering such matters as use of language (e.g., "To what extent is politics portrayed as a man's world by word usage'), use of illustrations (e.g., "How often do pictures/cartoons show women in secondary, supportive roles with males as central actors?'), use of examples or case studies (e.g., "Are women showcased in more important political roles and processes and men in less important ones?'), arrangement of material (e.g., "Is the information on women in politics segregated?'), and coverage of existing information about women in politics (e.g., "How much did you learn about women's interest group activities?). The survey concluded

\section{One of the most insidious and central problems of all is that women often perceive their burdens as uniquely theirs.}

with an open-ended section asking the reviewer such questions as "What specific words, paragraphs, pictures or sections do you recommend for deletion in the next edition?"'

What made the book by Welch and her colleagues the winner? To quote from one of the reviews: "This book includes more information and analysis of women's political participation than any other introductory text on American government. . . . This textbook ... analyzes politics sensitively. It does not explain away problems of elite rule for democracy or overlook the persistence of discrimination against women and other minorities even after formerly politically excluded groups are included as office-holders as well as voters . . . any student can read it, male or female, minority or member of the dominant group, and feel included and inspired to become politically active." West Publishing now uses the Caucus award in its advertising for the winning book, and it reports a significant increase in sales.

Other books fared less well. Overall rankings suggested that only
$20 \%$ of the books presently in the market could be considered adequate for the coverage of women's issues and women's participation in politics, with $80 \%$ ranging from mediocre to terrible. However, the poor reviews were not earned by the use of sexist language or open contempt for the role of women in politics. The problem with most introductory texts is that they had little material at all on women. There was little mention of their role in government, little material on political matters specifically relevant to women (e.g., the women's movement, sex quotas at party conventions, abortion, comparable worth, etc.), and little effort to explain sex discrimination in politics. Women were seldom used as role models and were inadequately represented in illustrations.

Contest number two is now underway. If you have written an introductory American government text you think may be a winner (or a new edition of a book that is now improved in its coverage of women), of if you would like a copy of the questionnaire, write to Barbara Burrell of Boston University, now chairing the caucus' American Government Textbook Award Committee. But hurry: the second award will be issued in 1991, and it takes time for a book to be reviewed.

The second Caucus committee I want to tell you about is new and just beginning its work. The idea for a women's platform came out of a discussion held in the spring of 1989 by a local caucus, Bay Area Women in Political Science (BAWPS), on whether there should be a women's political party. Unable to agree on that difficult question, the members of BAWPS concluded that in any case there should certainly be a women's platform. The idea has developed gradually and is now being worked on by Caucus members across the nation, giving new meaning to the Caucus commitment "to encourage the application of the skills of political science to the promotion of equal opportunities for all women."

The goal of the Women's Platform Committee is to construct a list of the political goals most women in the United States share, to stimulate further research on women's political issues, and to devise political strat- 
egies to assure the successful implementation of the platform.

Many other groups are, of course, already hard at work devising women's agendas and working for change. The Caucus seeks to make a contribution as political scientists, to link ourselves effectively to the actions of others outside our discipline and outside the academy, and to take a vital part in the task of revitalizing the women's movement in this nation.

We have decided that six steps must be taken to complete this project, and that the first four should be undertaken simultaneously. A Campus Inquiry Committee, led by Joyce Gelb, is appraising the policies and practices toward women in the academy. A Committee for Inquiry into Policy-Making Organizations, led by Judith Stiehm, will go beyond the campus into the governmental, business, voluntary, and professional associations where decisions are made regarding the delivery of services to women and their dependents. A Committee for Inquiry into Women's Political Organizations, led by Toni Travis, is concentrating on the agendas and strategies of women's political organizations; Jo Lee is collecting graduate student papers for a book on the subject. Louise Comfort is setting up a communications and information system, a computerized telecommunications system that will pool and organize all our work, and provide ease of access, utilization, and retrieval of information related to policies and practices affecting women. Louise is also working with Rita Mae Kelly and Marjorie LewisRice on a series of conferences designed to focus national attention on fundamental problems of policy and practice affecting women.

A platform accomplishes little unless it is endorsed by those with the power to transform its recommendations into action. Our sixth and final step will be the work of the Committee on Political Interaction, which will seek to employ the women's platform as a powerful instrument for effecting political change. The platform will be brought to the attention of local, state, and national media. It can be used by women in political parties and other organizations as they identify candidates for nomination or support in elections and by organizations lobbying for its implementation, as well as by the multitude of agencies that set economic and social policy affecting

Only 20\% of the books presently in the market could be considered adequate for the coverage of women's issues and women's participation in politics, with $80 \%$ ranging from mediocre to terrible.

women. Its combination of valid information, coupled with positive action, can help lead to a new national commitment to improve the condition of women in this society. To begin the work of this committee, Emily Stoper, Louise Comfort, and Laura Woliver set up three panels on the platform, composed of political practitioners and academics, for the 1990 meetings of the American Political Science Association.

The Women's Platform Project is bold and ambitious. It can and is being worked on by Caucus members across the nation, young and old, of every race, age, and status. It is nonpartisan and nondogmatic, constantly changing as we move along. If you are interested, write and join its work.

Is the platform too ambitious? Some might say so. But those of faint heart said back in 1969 that the very idea of a Women's Caucus was impossible. And just look what we have done.

\section{Notes}

1. The Association has published the following brochures:

Beverly B. Cook, Leslie F. Goldstein, Karen O'Connor and Susette M. Talarico, "Women in the Judicial Process,"' 1988.

Joyce Gelb and Ethel Klein, "Women's Movements: Organizing for Change," 1987.

Milda K. Hedblom, "Women and Power in American Politics," 1988.

Virginia Sapiro, "Women, Political Action and Political Participation," 1988.

Mary Lyndon Shanley, "Women's Rights, Feminism, and Politics in the United States," 1988.

\section{References}

Aisenberg, Nadya and Mona Harrington. 1988. Women of Academe: Outsider in the Sacred Grove. Amherst, MA: University of Massachusetts Press.

Cross, Amanda. 1986. Death in a Tenured Position. New York: Ballantine Books.

Houston Chronicle, November 6, 1989. "The Condition of the Professoriate: Attitudes and Trends 1989." A report by the Carnegie Foundation for the Advancement of Teaching.

Mitchell, Joyce M. 1990. "The Women's Caucus for Political Science: A View of the 'Founding.' " PS, June 1990, 204-209.

Mueller, John. 1970. "The Political Scientist Decides: An Examination of the 1969 APSA Ballots." PS, Summer 1970, 313.

Prestage, Jewel L. 1989. "Career Development Patterns of Black Women Political Science Doctorates: The Predoctoral Years." Presented at the annual meeting of the National Conference of Black Political Scientists, Baton Rouge. 